\title{
Hospital - primary care articulation in care transition: both sides of the process*
}

\author{
Articulação hospital - atenção primária na transição do cuidado: os dois lados do processo \\ Articulación hospital - atención primaria en la transición del \\ cuidado: las dos posibilidades del proceso
}

How to cite this article:

Mauro AD, Cucolo DF, Perroca MG. Hospital - primary care articulation in care transition: both sides of the process. Rev Esc Enferm USP. 2021;55:e20210145. DOI: https://doi.org/10.1590/1980-220X-REEUSP-2021-0145.

\section{Adriéli Donati Mauro ${ }^{1}$ \\ Danielle Fabiana Cucolo² \\ Marcia Galan Perroca ${ }^{1}$}

* Extracted from the thesis in progress (study stage completed in 2020) - Continuidade do cuidado ao paciente após a alta hospitalar: ações e tempo demandado pelo enfermeiro, a ser apresentado ao Programa de Pós-Graduação em Enfermagem da Faculdade de Medicina de São José do Rio Preto (FAMERP).

${ }^{1}$ Faculdade de Medicina de São José do Rio Preto, Programa de Pós-graduação em Enfermagem, São José do Rio Preto, SP, Brazil.

${ }^{2}$ Pontifícia Universidade Católica de Campinas, Programa de Pós-graduação, Campinas, SP, Brazil.

\begin{abstract}
Objective: To analyze how the articulation between hospital and primary health care related to patient discharge and continuity of care after hospitalization takes place. Method: Qualitative study, using the focus group technique to explore the experience of 21 nurses in hospitals $(n=10)$ and at primary care $(n=11)$ in a municipality in the northwest area of the State of São Paulo. Data collection took place between December 2019 and April 2020. Four focus groups were carried out (two in the hospital and two in the health units) and the findings underwent thematic analysis. Results: The categories identified were: Patient inclusion flow in the responsible discharge planning, Patient/ family member/caregiver participation, Care planning, Communication between services, and Challenges in the discharge process. According to reports, the discharge process is centered on bureaucratic aspects with gaps in communication and coordination of care. Conclusion: This research allowed understanding how nurses from different points of health care experience the discharge and (dis)articulation of the team work. The findings can equip managers in the (re)agreement of practices and integration of services to promote continuity of care.
\end{abstract}

\section{DESCRIPTOR}

Continuity of Patient Care; Process Assessment (Health Care); Patient Discharge; Nurse's Role; Patient-Centered Care. 


\section{INTRODUCTION}

The Health Care Networks ( $R A S$ ) encompass both actions and services articulated to promote equity, improve access, and ensure comprehensiveness and quality of care ${ }^{(1-2)}$. In Brazil, the regionalization of $R A S$, favored by the Brazilian Public Health System (SUS) Management Agreement, provides for the integration of different points: primary health care (PHC), specialized (outpatient and hospital) care, surveillance, work management, and health education; and assigns to the PHC the coordination of the patient's therapeutic pathway in a continuous movement for care $^{(3)}$.

The concept of continuity incorporates the patient's perspective in the experience of care and combines three elements: information flow, interpersonal relationships, and intervention coordination ${ }^{(4)}$. Therefore, it presupposes patients-health professionals interaction and connection sustained over time $\mathrm{e}^{(5)}$ and transition of care, that is, coordinated interventions between services during patient transference ${ }^{(6)}$.

In Brazil, the responsible hospital discharge is a guideline ${ }^{(7)}$ for transferring care from a specialized level (hospital) to other points in the $R A S$ and provides for articulation of services, promotion of self-care, and implementation of de-hospitalization mechanisms.

Some problems, however, still challenge the effectiveness of this process. The active and early participation of the patient/caregiver in the discharge planning of care $^{(8)}$, the transfer of information, and patient follow-up after hospitalization are weaknesses faced in hospital care $(H C)^{(9)}$. From the perspective of $\mathrm{PHC}$, adversities in the referral and counter-referral system ${ }^{(10)}$, failures in communication among teams ${ }^{(11)}$, lack of workers' knowledge about the functioning of $R A S^{(12)}$, little articulation ${ }^{(13)}$, and difficulties in coordination of network care ${ }^{(14)}$ are highlighted.

The nurse plays a central role in the discharge planning and has been a facilitator in the transition of care, coordinating actions and interactions among professionals, services, and with the patient/family to ensure continuity of care after hospitalization ${ }^{(15-16)}$. However, the identification of patients with continued care needs and the process of counter-referral and monitoring of the PHC can represent additional activities in the nurses' routine, generating work overload $^{(12)}$.

Although restrictions are identified, the articulation among hospitals and other $R A S$ services has hardly been evidenced in the literature ${ }^{(17)}$. Investigations on patient discharge and care transition address the issue unilaterally, from the perspective of $H C^{(8,18-19)}$ or $\mathrm{PHC}^{(10-11,20)}$. This study seeks to recognize the two sides of the process, from the perspective of nurses at these two levels of care, broadening the view on the continuity of care, the challenges of comprehensiveness, and the complexity of team work. Therefore, it aims at answering the following question: According to the nurses' experience, how does the articulation between hospital and primary health care regarding responsible discharge for continuity of patient care after hospitalization take place?
Linked to the research group Health and Nursing Services Management (GESTSAÚDE) and part of a broader approach, this initial stage of the master's project aims to analyze how the articulation between hospital and primary health care related to patients' responsible discharge and to continuity of care after hospitalization takes place.

\section{METHOD}

\section{Design of Study}

This descriptive study, with a qualitative approach, used the focus group (FG) technique to obtain information, explore experiences and opinions on the subject based on the interaction of the participants ${ }^{(21)}$. In its design, the guidelines of the Consolidated criteria for reporting qualitative research (COREQ) for qualitative research were adopted ${ }^{(22)}$.

\section{Local and Population}

It was decided that nurses from a private and teaching hospital, a Primary Health Unit (UBS), and 10 units of the Family Health Strategy (FHS) located in the northwest region of the State of São Paulo would be investigated. It is a reference hospital for 19 municipalities, with 198 beds and $60 \%$ of care provided by SUS, agreed with the State Health Department. The municipality has five UBS and 24 FHS teams managed by a Social Health Organization $(O S)$. The PHC nurses are hired by the $O S$ and carry out the coordination of the unit and of the team(s), besides assuming the care demands.

The sample of this study consisted of 21 nurses (10 from $\mathrm{HC}$ and 11 from PHC) appointed, for convenience, by the hospital's nursing manager and the technical coordinator of the PHC units. As inclusion criteria, in addition to participating in the responsible discharge process, nurses could not be in a probationary period and should be working in the units during the period of data collection.

\section{Data Collection}

To contact the indicated professionals, one of the researchers had the support of the nurse from the internal $H C$ regulation center and the coordinator of permanent education at the PHC. The invitation was made through email, highlighting the objective of the research, who would be the moderator, date, time and place of the meetings, and requesting confirmation from the participants. Of the 23 nurses contacted, only one declined the invitation for personal reasons and another was excluded for being in a period of professional experience. After the start of the COVID-19 pandemic, access was supported by the coordination of services and during FG sessions, the safety measures were followed.

Four FGs were held between December 2019 and April 2020, within the context of practice with nurses from HC, two meetings ( $\mathrm{n}=6$, morning and $\mathrm{n}=4$, afternoon), and from PHC, two other meetings ( $\mathrm{n}=6$, morning and $\mathrm{n}=5$, afternoon), totaling 21 participants. The sessions lasted an average of 60 minutes. The groups were led by a researcher with a graduate certificate in public health and experience 
in the management of the FHS, trained to conduct FGs. Sessions were recorded with prior authorization.

At the meetings, participants were informed about the objective of the research and signed the Free Informed Consent Form (FICF). Following this, guidelines were started regarding the filling of the categorization questionnaire, considering sociodemographic (age, gender) and occupational variables (final year of undergraduate studies, type of specialization, professional experience as a nurse, experience in the field, and time working in the unit). After filling the form, the guiding questions were read, which were also available in printed form, so that nurses could respond individually before opening for group discussions. They were: Is the responsible discharge instituted in the municipality? What is the flow and/or criteria established between the HC and the PHC for responsible discharge? How does communication between these two levels of care take place in view of the patient's discharge and the need to continue care in the community? What are the strategies adopted to ensure continuity of care after hospitalization? and What are the facilitating and hindering factors of this articulation?

The moderator encouraged the participation of all members in each FG taking notes and, at the end of the meetings, presented feedback on the main aspects discussed in each question. In addition, she allowed the debate on other experiences related to the theme, identifying the saturation of the findings.

\section{Data Analysis and Treatment}

Discussions were transcribed and analyzed according to content in the thematic modality ${ }^{(23)}$. In the material pre-analysis, data from the $\mathrm{HC}$ and $\mathrm{PHC}$ were organized, separately, and two researchers carried out the "thorough reading" and formulation of hypotheses based on the findings. Subsequently, the reports were explored, highlighting the registration units (phrases), coded into themes (by frequency/ representativeness) and grouped (data from $\mathrm{HC}$ and $\mathrm{PHC}$ ), by approximation or distance, into categories. The content was then appreciated, interpreted, and compared (similarities and differences) allowing inferences from the theoretical framework adopted concerning the responsible discharge (from the perspective of the organization and uniqueness of health services $)^{(7)}$, transition and continuity of care $e^{(1,3-5,14,17,20)}$. To ensure anonymity, nurses were identified with random letters and numbers (PHCN1, PHCN2, HCN1, HCN2...).

\section{Ethical Aspects}

The study was approved by the heads of the hospital institution and PHC units in the municipality where the study was conducted and by the Research Ethics Committee of the Centro Universitário Padre Albino (UNIFIPA), under opinion no. 3.699.970/2019. Ethical criteria were respected following the recommendations of Resolution no 466/2012 of the National Health Council.

\section{RESULTS}

In this study, all participants were female, with a mean age of $31.0(\mathrm{SD}=4.9$; range 25 to 43 ) years; average professional experience of $5.3(\mathrm{SD}=3.7$; range 0.92 to 14 ) years; length of experience at the UBS/FHS of 4.7 (SD = 2.2; range 1 to 8$)$ years and at $\mathrm{HC}$ of $6.0(\mathrm{SD}=4.9$; range 0.92 to 14 ) years. The most mentioned qualification was a graduate certificate in Public Health with emphasis on FHS ( $n=7)$ and Health Management $(n=2)$, among others. Four participants reported not having a graduate certificate.

After analyzing the reports, five thematic categories emerged. The first, "Flow of inclusion of the patient in the responsible discharge planning", deals with the eligibility criteria and the moment of inclusion of the patient in the discharge planning and identifies, in the speech of some nurses from $\mathrm{HC}$, the decision still centered on the physician. The PHC nurses confirm the existence of a pre-established flow for the transition of care, as shown below:

From the moment the patient is hospitalized and has any device, be it a tube, colostomy, nasoenteral tube, we start discharge (...) We update every day (HCN6).

When the doctor says that he is going to discharge, then the schedule is made ... needs some medication ... needs oxygen (...) (HCN5).

(...) before being discharged, they send the patient to the unit so that we can provide care (...) (PHCN9).

There is a flow and if there is any change, the hospital also sends a notification to us, saying that the discharge will no longer be scheduled, because there was a worsening or an improvement in the patient's condition... ( $\mathrm{PHCN} 8)$.

The second category brings reports from $\mathrm{HC}$ and PHC nurses on the transfer of information to the patient/family in view of the need for continued care, but the "Participation of the patient/family/caregiver in the responsible discharge process" may be limited to science as to the de-hospitalization and counter-referral process:

Professionals guide patients, it is a group and ends up opening a circle and communicating... if he/she [patient] has any doubts... we guide again (HCN3).

(...) I [the worker at the responsible discharge service] approach them [family members]... I inform them that a discharge protocol has been opened... they will await the municipality's return (...) if the family has any questions, I talk to the girls... they call me and we are in constant communication (HCN4).

(...) we wait for the family to seek attention, in the meantime we inform other professionals for them to be aware of this responsible discharge, to carry out this active search for the patient as soon as they are at home... (PHCN10).

(...) sometimes they discharge this patient... they think that primary care will develop all care (...) so... I ask the social worker to visit with me, advising the family or patient on what they need, and that the unit will be there to provide support, but care is provided by the family member ( $\mathrm{PHCN} 3$ ). 
The nurses mentioned the strategy adopted by each level of care for "Planning care in responsible discharge", third category, involving the health team, to predict and provide the necessary interventions and resources:

(...) multi visit is done daily... it is a team (...) Through this daily visit, post-discharge care is established (HCN5).

(...) with this visit... we already know what to do and speed it up (...) (HCN2).

Planning through the matrix meeting... Family Health Support Center, community agent, and nursing team that will provide care (...) (PHCN8).

(...) we already program ourselves... with materials... what will be used after discharge (...) (PHCN11).

(...) they have to provide a professional... to go to this patient's house, both to provide care and to train the family (PHCN10).

The concern with formalizing the information in the counter-referral process to carry out the responsible discharge was expressed in the fourth category, "Communication between hospital and primary health care", as highlighted by the reports:

(...) we use the care planning ... and the email (...) (HCN10).

Discharge only happens through an answer; we don't release the patient without this answer (...) (HCN4).

We receive an email with the discharge form... this email gives details about what primary care has to provide for this patient (...) (PHCN 9).

\section{(...) the hospital needs to receive a return that oxygen is installed} in the household (PHCN1).

The fifth category, "Challenges in the responsible discharge process", groups the nurses' statements into six sub-themes, demonstrating the internal view of the hospital and the PHC as opposed to the articulation between services and the uniqueness of the health system:

1. Discharge uncoordinated with the responsible discharge planning

The doctor's hospital discharge... happens at any time, so the doctor can arrive here out of business hours to discharge this patient, and then this makes things difficult... (HCN10).

2. Communication between services

(...) this interaction is lacking within the network itself, bow does it work if... there are three processes I forward to three different primary care professionals and then there is no such interaction among them ( $\mathrm{HCN} 4)$.

3. PHC response deadline

I think the response time is the real hindering factor... the municipality has 72 hours to respond so... the patient occupies an inpatient bed (...) (HCN4).
4. Clarity of $\mathrm{HC}$ records

(...) the hospital form we received by e-mail... sometimes we cannot read and understand what is written because it is scanned, sometimes information is incomplete (PHCN6).

5. Integration of RAS services

(...) they [hospital service] do not know how it works within a unit and what we can offer (...) (PHCN6).

6. Continuity of care in $\mathrm{PHC}$

(...) the responsible discharge is opened when the patient is admitted to the hospital and then it is not developed (...) (PHCN1).

(...) the family forms a link with the unit so that we can have this attention, but during the weekend, sometimes [care] is not exercised (PHCN10).

(...) the hardest part is... the family can't... provide support... the family can't organize itself for this (...) (PHCN8).

(...) The lack of communication sometimes gets in the way (...) the patient's lack of understanding... he comes to the health center thinking that we will solve everything that was requested and that is often not the case (PHCN2).

Considering the principles and guidelines of national policies $^{(1,7)}$, the participants' responses were grouped into articulated actions and others that still need to be strengthened (Figure 1).

\section{DISCUSSION}

The responsible hospital discharge is established in the $R A S$ of the municipality under study and, in the reports by nurses from the $\mathrm{HC}$ and the PHC, administrative instruments (flow, strategies for planning and communication between services) are highlighted, denoting a process that is still bureaucratic.

In addition, the literature ${ }^{(16,24)}$ emphasizes the start of discharge planning within the first 24 hours after admission and, even with pre-established criteria for patient inclusion, hospital nurses diverge as to the initial moment of the plan with indications of medical control over the process. The collaboration of different professionals in preparing the patient for discharge is essential ${ }^{(16)}$ but, in these nurses' experience, the physician does not always follow what is determined in the flow and what was discussed by the teams/ services, impairing the dynamics and continuity of work.

In the context under study, although nurses report clarification of doubts and of the planned actions for discharge, the patient/family member/caregiver acts as a listener and is passively inserted in the process, often not being able to make an autonomous search for the PHC service and to provide care at home.

The active participation of the patient in the process of discharge and care transition, as well as the effective orientation and integration of the family member/caregiver, are highlighted internationally ${ }^{(15-16)}$ and in Brazilian guidelines ${ }^{(7)}$. However, the still fragile involvement of these actors affects the continuity of care at home ${ }^{(8)}$. Discharge planning is more 


\section{PRINCIPLES AND GUIDELINES}

Patient/family autonomy, continuity of care and de-hospitalization*

Integrality, person-centered care, longitudinality of care and problem-solving capacity $\dagger$

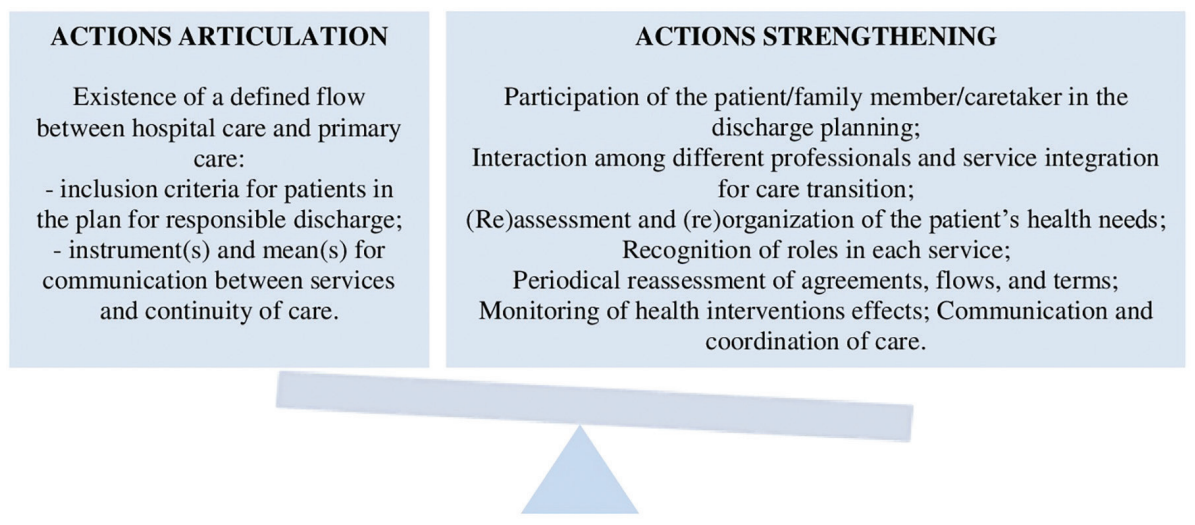

Figure 1 - Articulation between services in the transition of care and actions that need to be strengthened, 2019.

effective when care is centered on the patient, as patients feel more competent for self-care when they leave the institution and stay in the hospital for a shorter time ${ }^{(24)}$.

The findings also demonstrate the transfer of patients from $\mathrm{HC}$ to $\mathrm{PHC}$ focused on communication demands (equipment and necessary supplies) by email, and do not show other mechanisms for agreement and articulation of services for care transition ${ }^{(6)}$. Other elements necessary to avoid discontinuation of care ${ }^{(4-5)}$ were not addressed by nurses. Among them, the role of the PHC as the orderer of care and coordinator of RAS at SUS is not evident, unlike another investigation $^{(14)}$.

Care coordination can be performed specifically among health professionals and both nurses and physicians have significant participation in the articulations between services $^{(14)}$. In Chile, $\mathrm{HC}$ nurses concentrate their efforts to qualify the discharge process and team work, but, as in the present study, they do not have a formal monitoring system coordinated with the PHC, which may imply risks for the patient ${ }^{(25)}$ with potential impacts on the clinical outcome ${ }^{(26)}$.

In the Canadian ${ }^{(16)}$ and Spanish ${ }^{(27)}$ experiences, nurses (called liaison nurses) are responsible for assessing the patients' needs (through active search or at the request of professionals or family members) and coordinating strategies with the teams of $H C$ and extra-hospital services for continuity of post-discharge care.

In Brazil, more specifically in the State of São Paulo, there are professionals (articulators) to support integration activities between institutions, develop assessment, monitoring, and education actions in the PHC, strengthening municipal management ${ }^{(28)}$. This feature, however, does not appear in the discussions and may not act directly with nurses in the discharge and care transition process.

Care actions also did not emerge in FG, neither in $H C$ nor in PHC. This gap may be related to the operational approach of the process anchored by triggering questions and/or may show the administrative workload assumed by nurses when the patient is discharged, to the detriment of the care process ${ }^{(29)}$.

According to the reports, the moment of discussion by the $H C$ team in the daily bedside visits and the matrix support meetings of the team(s) of the UBS/FHS and of the Family Health Support Center (NASF) are powerful interprofessional collaboration strategies for discharge. These spaces for dialogue and interaction among the subjects facilitate the articulation of health care proposals ${ }^{(27)}$, but they are still carried out, in isolation, in each center (hospital and primary care).

Strategies for approaching and including $\mathrm{HC}$ professionals in PHC meetings and vice versa, perhaps, would solve a challenge highlighted by nurses regarding the recognition of professional skills, structure and limitations of the services that form $R A S$. On the contrary, the lack of knowledge about the services can generate even more disarticulation of actions and fragmentation in patient care.

The flow of communication among the levels of care corroborates the Portuguese experience in discharge management ${ }^{(30)}$. However, the counter-referral process and the integration between the $R A S$ services need to be improved because the responsibility for transferring the information often rests with the patient/family ${ }^{(9)}$. A computerized and integrated system is suggested, to be added to telephone contact after discharge, but, so far, this is not the reality of the Brazilian $R A S^{(12,14)}$.

The lack of updating of the discharge plan during hospitalization is a critical aspect of communication because when the patient returns to the community, the planning no longer meets the care needs. In addition, there is a lot of information that is not registered, is not clear or is illegible and this corroborates the findings of another investigation ${ }^{(14)}$. The relationships established between professionals and the information provided between services are elements that ensure the continuity of care ${ }^{(11)}$. 
Another challenge reported by the HC nurses is the agility of the PHC response (before 72 hours), thus meeting the patient's conditions for discharge, the demands for hospitalization (bed occupancy) and the de-hospitalization process anticipated in the responsible discharge movement ${ }^{(7)}$. In this regard, $R A S$ services shall establish an active channel of communication and follow-up at discharge, ensuring feedback and planning for the continuity of care ${ }^{(25)}$.

It is urgently inferred that there is a need to bring $R A S$ points together and integrate them to overcome the bureaucratization and fragmentation of health care. These aspects can be aggravated by chronic underfunding and expansion of private initiatives in the management of public resources, as is the case with $O S^{(2)}$.

The findings of this study represent the experience of nurses in a Brazilian municipality and may differ from other realities, requiring further studies for comparison and/or further discussions on the subject. We also opted for homogeneous FG (professionals at the same level of care) and additional results on articulation could be identified by bringing nurses from the $\mathrm{HC}$ and $\mathrm{PHC}$ together at the same time. Reports presented and discussed in this research considered the various specialties together. Future investigations may address more specificities.

Responsible hospital discharge, as a national guideline ${ }^{(7)}$, has not yet completed a decade and represents a new and complex process, as it depends on effective team work. Therefore, this study can contribute to the improvement of this practice in the $R A S$, with particular attention being given to the strengthening of actions in different points of care, since it represents a view of professionals who work on both sides of this process. In addition, it can support managers in the implementation and consolidation of this strategy, taking the political principles and guidelines of the Brazilian health system into account.

\section{CONCLUSION}

The articulation of actions for discharge planning and continuity of care for the patient after hospitalization are centered, according to the reports of nurses from the $\mathrm{HC}$ and PHC, on the fulfillment of administrative protocols. In this scenario, there are strong conflicts and barriers in the communication flow, polarization between institutions (hospital PHC) and weakness in the coordination of care. The findings suggest the appropriation of other mechanisms of agreement and articulation of services for the transition of care.

For better team work and strengthening of actions for discharge and continuity of care, the following is recommended: to include the patient/family member/caregiver as a team member in care planning; to systematize care for discharge, developing each case throughout hospital stay; to improve communication mechanisms between professionals and services; to assess the effectiveness of interventions planned and implemented after discharge; to follow the patient through health care (care coordination); to integrate professionals from different points of care in service meetings; and to analyze the adopted care transition model (responsible hospital discharge) by reviewing flows, deadlines, and agreements and also considering other models that could be implemented/combined.

\section{RESUMO}

Objetivo: Analisar como ocorre a articulação entre a atenção hospitalar e primária à saúde relacionada à alta do paciente e à continuidade do cuidado após internação hospitalar. Método: estudo qualitativo, utilizando a técnica de grupo focal para explorar a experiência de 21 enfermeiros da atenção hospitalar $(n=10)$ e primária $(n=11)$ de um município da região noroeste do Estado de São Paulo. A coleta dos dados ocorreu entre dezembro de 2019 e abril de 2020. Foram realizados quatro grupos focais (dois no hospital e dois nas unidades de saúde) e os achados foram submetidos à análise temática. Resultados: As categorias identificadas foram: Fluxo de inclusão do paciente no plano de alta responsável, Participação do paciente/familiar/cuidador, Planejamento dos cuidados, Comunicação entre os serviços e Desafios no processo de alta. Segundo os relatos, o processo de alta está centrado em aspectos burocráticos com lacunas de comunicação e coordenação do cuidado. Conclusão: Esta pesquisa possibilitou compreender como enfermeiros de diferentes pontos de atenção à saúde vivenciam a alta e a (des)articulação do trabalho em rede. Os achados podem instrumentalizar gestores na (re) pactuação de práticas e integração dos serviços para promoção da continuidade do cuidado.

\section{DESCRITORES}

Continuidade da assistência ao paciente; Avaliação de Processos (Cuidados de Saúde); Alta do paciente; Papel do profissional de enfermagem; Assistência centrada no paciente.

\section{RESUMEN}

Objetivo: Analizar como ocurre la articulación entre la atención hospitalaria y primaria a la salud relacionada al alta del paciente y la continuidad del cuidado tras hospitalización. Método: estudio cualitativo que utilizó la técnica de grupo focal para explotar la experiencia de 21 enfermeros de la atención hospitalaria $(n=10)$ y primaria $(n=11)$ de un municipio de la región noroeste del Estado de São Paulo. La recolección de los datos ocurrió entre diciembre de 2019 y abril de 2020 . Fueron realizados cuatro grupos focales (dos en el hospital y dos en los centros de salud) y los hallazgos fueron sometidos al análisis temático. Resultados: Las clases identificadas fueron: Flujo de inclusión del paciente en el plano de alta responsable, Participación del paciente/familiar/cuidador, Organización de los cuidados, Comunicación entre los servicios y desafíos en el proceso de alta. Según los relatos, el proceso de alta está centrado en aspectos burocráticos con irregularidades de comunicación y coordinación del cuidado. Conclusión: Esta investigación hizo posible comprender como enfermeros de diferentes centros de atención a la salud vivencian el alta y la desarticulación del trabajo en red. Los hallazgos pueden instrumentalizan gestores en la (re)pactuación de prácticas e integración de los servicios para la promoción de la continuidad del cuidado. 


\section{DESCRIPTORES}

Continuidad de la Atención al Paciente; Evaluación de Procesos y Resultados en Atención de Salud; Alta del Paciente; Rol de la Enfermera; Atención Dirigida al Paciente.

\section{REFERENCES}

1. Brasil. Ministério da Saúde. Portaria n. 2.436, de 21 de setembro de 2017. Aprova a Política Nacional de Atenção Básica, estabelecendo a revisão de diretrizes para a organização da Atenção Básica, no âmbito do Sistema Único de Saúde (SUS). Diário Oficial da União, Brasília, 2017. Seção 1, p. 68.

2. Paim JS. Universal health systems and the future of the Brazilian Unified Health System (SUS). Saúde Debate. 2019;43(spe5):15-28. DOI: http://dx.doi.org/10.1590/0103-11042019S502.

3. Damaceno AN, Lima MADS, Pucci VR, Weiller TH. Health care networks: a strategy for health systems integration Redes de Atención de salud: una estrategia para la integración de los sistemas de salud. Rev Enferm UFSM. 2020;10:1-13. DOI: http://dx.doi. org/10.5902/2179769236832.

4. Villalon GE. Continuidad del cuidado. Evid Actual Pract Ambul [Internet]. 2021 [cited 2021 June 14];21(1):e002112. Available from: http://www.evidencia.org/index.php/Evidencia/article/view/6922/4524.

5. Meiqari L, Al-Oudat T, Essink D, Scheele F, Wright P. How have researchers defined and used the concept of 'continuity of care' for chronic conditions in the context of resource-constrained settings? A scoping review of existing literature and a proposed conceptual framework. Health Res Policy Syst. 2019;17(1):27. DOI: http://dx.doi.org/10.1186/s12961-019-0426-1.

6. Joint Commission Center for Tranforming Healthcare [Internet]. Oakbrook Terrace: The Joint commission; c2012 [cited 2021 June 14 ]. Available from: https://www.jointcommission.org/-/media/deprecated-unorganized/imported-assets/tjc/system-folders/topics-library/hot_ topics_transitions_of_carepdf.pdf?db = web\&hash = CEFB254D5EC36E4FFE30ABB20A5550E0.

7. Brasil. Ministério da Saúde. Portaria n. 3.390, de 30 de dezembro de 2013. Institui a Política Nacional de Atenção Hospitalar (PNHOSP) no âmbito do Sistema Único de Saúde (SUS), estabelecendo-se as diretrizes para a organização do componente hospitalar da Rede de Atenção à Saúde (RAS). Diário Oficial da União, Brasília, 2013. Seção 1, p. 54.

8. Mitchell SE, Laurens V, Weigel GM, Hirschman KB, Scott AM, Nguyen HQ, et al. Care transitions from patient and caregiver perspectives Ann Fam Med. 2018;16(3):225-31. DOI: http://dx.doi.org/10.1370/afm.2222.

9. Acosta AM, Câmara CE, Weber LAF, Fontenele RM. Nurse's activities in care transition: realities and challenges. Rev Enferm UFPE on line. 2018;12(12):3190-7. DOI: http://dx.doi.org/10.5205/1981-8963-v12i12a231432p3190-3197-2018.

10. Brondani JE, Leal FZ, Potter C, Silva RM, Noal HC, Perrando MS. Challenges of referral and counter-referral in health care in the workers' perspective. Cogitare Enferm. 2016;21(1):1-6. DOI: http://dx.doi.org/10.5380/ce.v21i1.43350.

11. Mendes MLG, Gemito Ermelinda CCP, Serra IC, Novas MVC. Continuity of care from the perspective of users. Ciênc Saúde Coletiva. 2017;22(3):843-55. DOI: http://dx.doi.org/10.1590/1413-81232017223.26292015.

12. Ribas EN, Bernardino E, Larocca LM, Poli Neto P, Aued GK, Silva CPC. Nurse liaison: a strategy for counter-referral. Rev Bras Enferm. 2018;71(Suppl 1):546-53. DOI: http://dx.doi.org/10.1590/0034-7167-2017-0490.

13. Peiter CC, Santos JLG, Lanzoni GMM, Mello ALSF, Costa MFBNA, Andrade SR. Healthcare networks: trends of knowledge development in Brazil. Esc Anna Nery. 2019;23(1):e20180214. DOI: http://dx.doi.org/10.1590/2177-9465-ean-2018-0214.

14. Ribeiro SP, Cavalcanti MLT. Primary Health Care and Coordination of Care: device to increase access and improve quality. Ciênc \& Saúde Coletiva. 2020;25(5):1799-808. DOI: http://dx.doi.org/10.1590/1413-81232020255.34122019.

15. Martins MM, Aued GK, Ribeiro OMPL, Santos MJ, Lacerda MR, Bernardino E. Discharge management to ensure continuity of care: experience of Portuguese Liaison Nurses. Cogitare Enferm. 2018;23(3):e58449. DOI: http://dx.doi.org/10.5380/ce.v23i3.58449.

16. Aued GK, Bernardino E, Lapierre J, Dallaire C. Liaison nurse activities at hospital discharge: a strategy for continuity of care. Rev Latinoam Enferm. 2019;27:e3162. DOI: http://dx.doi.org/10.1590/1518-8345.3069.3162.

17. Weber LAF, Lima MADS, Costa AM, Marques GQ. Care transition from hospital to home: integrative review. Cogitare Enferm. 2017;(22)3:e47615. DOI: http://dx.doi.org/10.5380/ce.v22i3.47615.

18. Silva KL, Sena RR, Castro WS. Dehospitalisation at a general hospital in Minas Gerais: challenges and prospects. Rev Gaúcha Enferm. 2017;38(4):e67762. DOI: https://doi.org/10.1590/1983-1447.2017.04.67762.

19. Costa MFBNA, Andrade SR, Soares CF, Ballesteros Pérez El, Capilla Tomás S, Bernardino E. The continuity of hospital nursing care for Primary Health Care in Spain. Rev Esc Enferm USP. 2019;53:e03477. DOI: http://dx.doi.org/10.1590/s1980-220x2018017803477.

20. Fagundes PF, Scandol EMR. Responsible hospital discharge under the perspective of health care network. Serv Soc. 2018;17(1):181-204. DOI: http://dx.doi.org/10.20396/sss.v17i1.8655207.

21. Jayasekara RS. Focus group in nursing research: methodological perspectives. Nurs Outlook. 2012;60(6):411-6. DOI: http://dx.doi. org/10.1016/j.outlook.2012.02.001.

22. Tong A, Sainsbury P, Craig J. Consolidated criteria for reporting qualitative research (COREQ): a 32-item checklist for interviews and focus groups. Int J for Qual Health Care. 2007;19(6):349-57. DOI: http://dx.doi.org/10.1093/intqhc/mzm042.

23. Bardin L. Análise de conteúdo. São Paulo: Edições 70; 2011.

24. Ulin K, Olsson LE, Wolf A, Ekman I. Person-centred care - An approach that improves the discharge process. Eur J Cardiovasc Nurs. 2016;15(3):e19-26. DOI: http://dx.doi.org/10.1177/1474515115569945.

25. Guzmán MCG, Andrade SR, Ferreira A. Role of nurses for continuity of care after hospital discharge. Texto Contexto Enferm. 2020;29(Spe):e20190268. DOI: http://dx.doi.org/10.1590/1980-265x-tce-2019-0268. 
26. Hadad ACC, Jorge AO. Continuidade do cuidado em rede e os movimentos de redes vivas nas trajetórias do usuário-guia. Saúde Debate. 2018;42(Spe 4):198-210. DOI: http://dx.doi.org/10.1590/0103-11042018S416.

27. Costa MFBNA, Andrade SR, Soares CF, Ballesteros Pérez El, Capilla Tomás S, Bernardino E. The continuity of hospital nursing care for Primary Health Care in Spain. Rev Esc Enferm USP. 2019;53:e03477. DOI: http://dx.doi.org/10.1590/S1980-220X2018017803477.

28. Ordoñez LKB, Arantes CIS. Conceptions, practices and perspectives of collective health actions: Optics of basic attention articulators. Rev Enferm Cent.-Oeste Min. 2018;8:e2587. DOI: http://dx.doi.org/10.19175/recom.v8i0.2587.

29. Rustad EC, Cronfalk BS, Furnes B, Dysvik E. Continuity of Care during CareTransition: Nurses' Experiences and Challenges. Open J Nurs. 2017;7(2):277-293. DOI: http://dx.doi.org/10.4236/ojn.2017.72023.

30. Guerrero KS, Puls SE, Andrew DA. Transition of care and the impact on the environment of care. J Nurs Educ Pract. 2014;4(6):30-6. DOI: http://dx.doi.org/10.5430/jnep.v4n6p30. 